\title{
18. REPORT ON LARGER FORAMINIFERA FROM SITES 4 AND 5
}

\author{
K. N. Sachs, Jr., U. S. Geological Survey, Washington, D. C.
}

The larger foraminifera in the following samples were examined and identified. Many of the identifications are tentative or questionable due to the poor state of preservation, and some of them are based on single specimens. However, the age ranges for the samples are well documented and tie in with the results of other studies, notably those on the planktonic foraminifera (see Chapters 4, 5, and 25).

\section{Tertiary Foraminifera}

\section{Site 4}

Sample 1-4-1-1, top:

Lepidocyclina sp. cf. L. pustulosa (Douville), L. yurnagunensis Cushman; L. undosa Cushman; Dictyoconus floridanus (Cole); Amphistegina sp.; "Nummulites" sp. Age: Middle Eocene - upper Oligocene.

Sample 1-4-1-1, $100 \mathrm{~cm}$ :

Lepidocyclina tournoueri Lemoine \& Douvillé; L. macdonaldi Cushman; L. undosa? Cushman; Asterocyclina sp.; Dictyoconus floridanus? (Cole); Eoconuloides wellsi Cole \& Bermudez; Amphistegina sp.

Age: Middle Eocene - Lower Miocene.

Sample 1-4-1-2, 0-2 cm:

Lepidocyclina yurnagunensis Cushman; Lepidocyclina sp.; Dictyoconus floridanus (Cole).

Age: Middle Eocene - upper Oligocene.

Sample 1-4-1-3, 3-4 cm:

Lepidocyclina yurnagunensis Cushman; L. canellei Lemoine \& Douvillé; Dictyoconus floridanus (Cole);

Eoconuloides? sp.; "Nummulites" sp.

Age: Middle Eocene - upper Oligocene or Lower Miocene.

Sample 1-4-1-4, 0-2 cm:

Lepidocyclina canellei Lemoine \& Douvillé; Lepidocyclina sp. cf. L. macdonaldi Cushman; Asterocyclina sp.

Age: Upper Eocene - upper Oligocene or Lower Miocene.

Sample 1-4-1-5, 0-2 cm:

Lepidocyclina yurnagunensis Cushman.

Age: Upper Oligocene.

Site 5

Sample 1-5-1-2, 1-10 cm:

Lepidocyclina canellei Lemoine \& Douvillé; L. vaughani
Cushman; Miogypsina (Miogypsina) sp.; Dictyoconus sp.; Amphistegina.

Age: Middle? Eocene - Miocene.

Sample 1-5-1-2, 33-36 cm:

Eoconuloides sp.; Amphistegina sp.; "Nummulites"sp. Age: Middle Eocene or younger.

Sample 1-5-1-3, 15-18 cm:

Lepidocyclina sp.; (a single microspheric individual) Age: Probably Oligocene - Miocene.

The considerable span in age of species within most of the individual samples above indicates extensive transportation and mixing of material from sources ranging, at least, from mid-Eocene through Lower Miocene in age. Such faunal mixing is most suggestive of turbidite deposits.

\section{Cretaceous Foraminifera}

The following samples were submitted from Hole 4A, and species of larger foraminifera were identified:

1-4A-1-1, 9-10 cm:

1-4A-1-1, $105 \mathrm{~cm}$ :

1-4A-1-2, 0-2 cm:

$1-4 \mathrm{~A}-1-2,100 \mathrm{~cm}$ :

1-4A-1-2, $109 \mathrm{~cm}$ :

$1-4 \mathrm{~A}-1-3,13-14 \mathrm{~cm}$ :

$1-4 \mathrm{~A}-1-13,61-63 \mathrm{~cm}$ :

Sulcoperculina globosa de Cizancourt; Vaughanina cubensis minor Seiglie \& Ayala-Castanares; Conorbitoides cristalensis Bronnimann; Orbitoides sp. cf. $O$. tissoti Schlumberger.

$S$. globosa and $V$.cubensis minor were the most abundant species, and they were found in all of the samples. $C$. cristalensis was represented by single specimens in two of the samples (1-4A-1-1, $105 \mathrm{~cm}$ and 1-4A-1-13, 61-63 $\mathrm{cm}$ ), and a single specimen of $O$. tissoti was found in Sample 1-4A-1-3.

The known stratigraphic distribution of these species confirms the age determination, made on the basis of smaller foraminifera (Chapters $4,5, \& 25$ ), as uppermost Campanian. According to Brown and Bronnimann (1957); "Sulcoperculina is generally found in the fore reef environment of the reef complex. However, where it occurs in large numbers with few other foraminifera, 
it may be indicative of a back reef environment". Although there is insufficient evidence based on the larger foraminifera above to support a distinction between fore or back reef origin for these samples, they most certainly came from a relatively shallow-water reef complex environment.

\section{REFERENCE}

Brown, N. K. \& Bronnimann, P., 1957. Some Upper Cretaceous rotaloids from the Caribbean region. Micropaleontology, 3, (1), 29. 